\title{
Trans-Atlantic rafting by the brooding reef coral Favia fragum on man-made flotsam
}

\author{
Bert W. Hoeksema ${ }^{1, *}$ Piet J. Roos $^{2,4}$ Gerhard C. Cadée $^{3}$ \\ Department of Marine Zoology, Netherlands Centre for Biodiversity Naturalis, PO Box 9517, 2300 RA Leiden, \\ The Netherlands
}

${ }^{2}$ Netherlands Centre for Biodiversity Naturalis (Section ZMA), University of Amsterdam, PO Box 94766, 1090 GT Amsterdam, The Netherlands

${ }^{3}$ Royal Netherlands Institute for Sea Research, PO Box 59, 1790 AB Den Burg, Texel, The Netherlands

${ }^{4}$ Present address: Rembrandt van Rijnweg 8, 1191 GG Ouderkerk aan de Amstel, The Netherlands

\begin{abstract}
Specimens of the brooding reef coral Favia fragum were found on man-made flotsam stranded on the North Sea shore of the Netherlands. Based on the associated epifauna originating from the southeast USA, we estimate that the corals must have crossed the Atlantic Ocean, transported by the Gulf Stream and the North Atlantic Drift. The size of the corals suggests that they might have had enough time to cross the Atlantic alive and that they already reached the age of possible self-fertilization before they entered waters that were too cold to survive. The temperature requirements and the presently known geographic range of $F$. fragum are compared with Atlantic summer and winter isotherms and oceanic currents in order to project a hypothetical northernmost range boundary. With increasing pollution, man-made flotsam may become a progressively more common substrate for reef corals that depend on rafting for long-distance dispersal. Eventually, with warming seawater, floating debris may cause tropical marine species to expand their distribution ranges towards higher latitudes.
\end{abstract}

KEY WORDS: Distribution range $\cdot$ Epifauna $\cdot$ Life history $\cdot$ Long-distance dispersal $\cdot$ Ocean currents · Temperature tolerance

\section{INTRODUCTION}

Many species of shallow-water marine benthic invertebrates use rafting for long-distance dispersal. Buoyant plant material, such as macroalgae thalli, seagrass leaves, and driftwood, is commonly known as a biotic carrier for epifaunal communities despite exposure to air, strong temperature fluctuations, and harmful UV-radiation at the sea surface (Cheng 1975, Thiel \& Gutow 2005a, b, Fraser et al. 2011). The success of dispersal depends on the size, buoyancy, and permanence of the floating substrate (particularly if organic), the longevity of the sessile phase in their life cycle, and the course and velocity of the carrying currents and winds. Eventually the floating objects may become cast up onshore, which is evi- dent on beaches around the world (Harrold \& Lisin 1989, Thiel \& Gutow 2005a).

Anthropogenic flotsam and jetsam consisting of non-biodegradable debris have a long durability and increasingly are becoming more common on beaches than natural floating substrata (Thiel \& Gutow 2005a). The litter usually originates from land via river mouths and drainage outlets and rarely as a result of storms and tsunamis. Shipping activities (merchant vessels), offshore industry, fisheries, and garbage dumping by coastal communities may also play a role in the production of marine debris, although only part of it is floating (Jones 1995, Hess et al. 1999, Donohue et al. 2001, Thiel \& Gutow 2005a, Richards \& Beger 2011), and predominantly consists of fisheries gear and packaging materials 


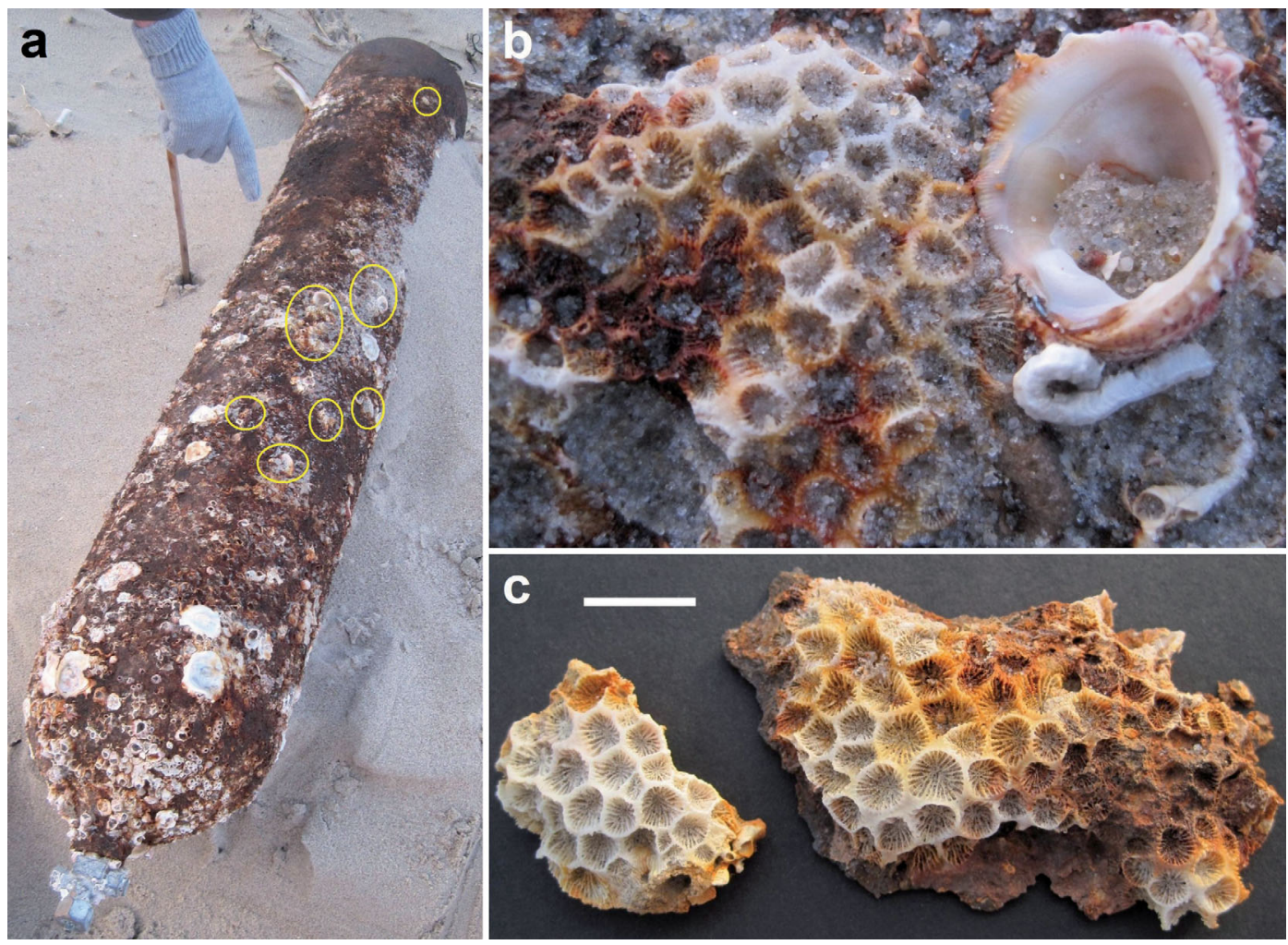

Fig. 1. Favia fragum. Gas cylinder (1.5 m long) with remnants of tropical epifauna washed ashore on the North Sea beach of Texel, The Netherlands. (a) The cylinder probably 3 yr after its stranding (positions of corals encircled). (b) Dead encrusting coral on cylinder together with an empty tube of a serpulid polychaete and a shell of the bivalve Chama congregata. (c) Specimens removed from their rusty substrate (RMNH Coel. 39909; scale bar: $1 \mathrm{~cm}$ )

(Uneputty \& Evans 1997, Willoughby et al. 1997, Derraik 2002, Thiel et al. 2003, Taffs \& Cullen 2005, Gregory 2009, Ryan et al. 2009).

The growth in man-made flotsam also causes an increase of buoyant substrate for benthic organisms, which has become most evident in areas where it used to be rare (Barnes 2002, Aliani \& Molcard 2003). Fouling organisms are able to reach remote coastlines as long as their growing weight does not negatively affect the buoyancy of their substrate. Eventually, long-lasting flotsam can become responsible for the introduction of exotic species (Winston 1982, Winston et al. 1997, Barnes \& Fraser 2003, Barnes \& Milner 2005). When these exotic species appear to colonize new areas and become harmful to allochtonous species, it is important to know their origin and natural environment for their control.

Recently, several specimens of the brooding amphiAtlantic reef coral Favia fragum (Esper, 1793), together with other fouling animals, were discovered on a gas cylinder that was beached on Texel, the Netherlands, (Fig. 1). Although the corals were dead, they were large enough to tell that they must have sur- vived for a long time. So far, it has only been hypothesised that the wide distribution range of brooding organisms, and $F$. fragum in particular, may be caused by long-distance dispersal through rafting (Highsmith 1985, Goodbody-Gringley et al. 2010). Based on the species composition of the epifauna of the cylinder, the course of oceanic currents, the size and growth form of the corals, and information on the biogeography and life history of $F$. fragum, we reconstruct a scenario in order to explain how these reef corals were able to reach the temperate coastline of the Netherlands.

\section{MATERIALS AND METHODS}

A $1.5 \mathrm{~m}$ long, rusty metal gas cylinder covered by abraded encrusting tropical epifaunal remains (Fig. 1a) was examined (29 November 2009) on the North Sea beach of Texel, the westernmost of the Frisian Islands. A report in the local newspaper resulted in comments from readers testifying that the cylinder must have been lying there for at least $3 \mathrm{yr}$. The epi- 
fauna consisted of several specimens of the Atlantic coral Favia fragum, barnacles, bryozoans, serpulids, and bivalves. The encrusting corals were removed from the metal cylinder with a knife to enable their identification using a binocular dissecting microscope. They were compared with an illustration of the type specimen of $F$. fragum (Esper, 1793) and with specimens from various localities in the coelenterate reference collection of Netherlands Centre for Biodiversity Naturalis, Leiden Naturalis (catalogued as RMNH Coel. and ZMA Coel.) in order to verify their identity. They were also compared with the types of F. gravida (Verrill, 1868), which also has an amphi-Atlantic distribution range (Laborel 1974, Hoeksema 2012). These specimens (YPM 1465a, 1465b, 4549) were sent on loan from the Yale Peabody Museum of Harvard University at New Haven, Connecticut, USA.

After the analysis, 2 beached specimens (Fig. 1c) were deposited in the collection of NCB Naturalis as reference material (RMNH Coel. 39909). We com- pared the distribution range of Favia fragum with the course of North Atlantic currents in order to retrace the cylinder's journey. Furthermore we reviewed the life history and habitat requirements of the species and compared these with summer and winter surface seawater isotherms in order to estimate the age of the corals and how far they could have travelled when still alive.

\section{RESULTS}

\section{Identity of the beached corals}

The beached corals were small $(\varnothing<5.5 \mathrm{~cm})$ and encrusting (Fig. 1). Despite their abraded condition, they could be identified as Favia fragum based on skeletal characters when compared to undamaged specimens (Fig. 2). F. fragum shows much variation in skeleton morphology (Roos 1971). The corals are usually small $(\varnothing<10 \mathrm{~cm})$, encrusting or massive and
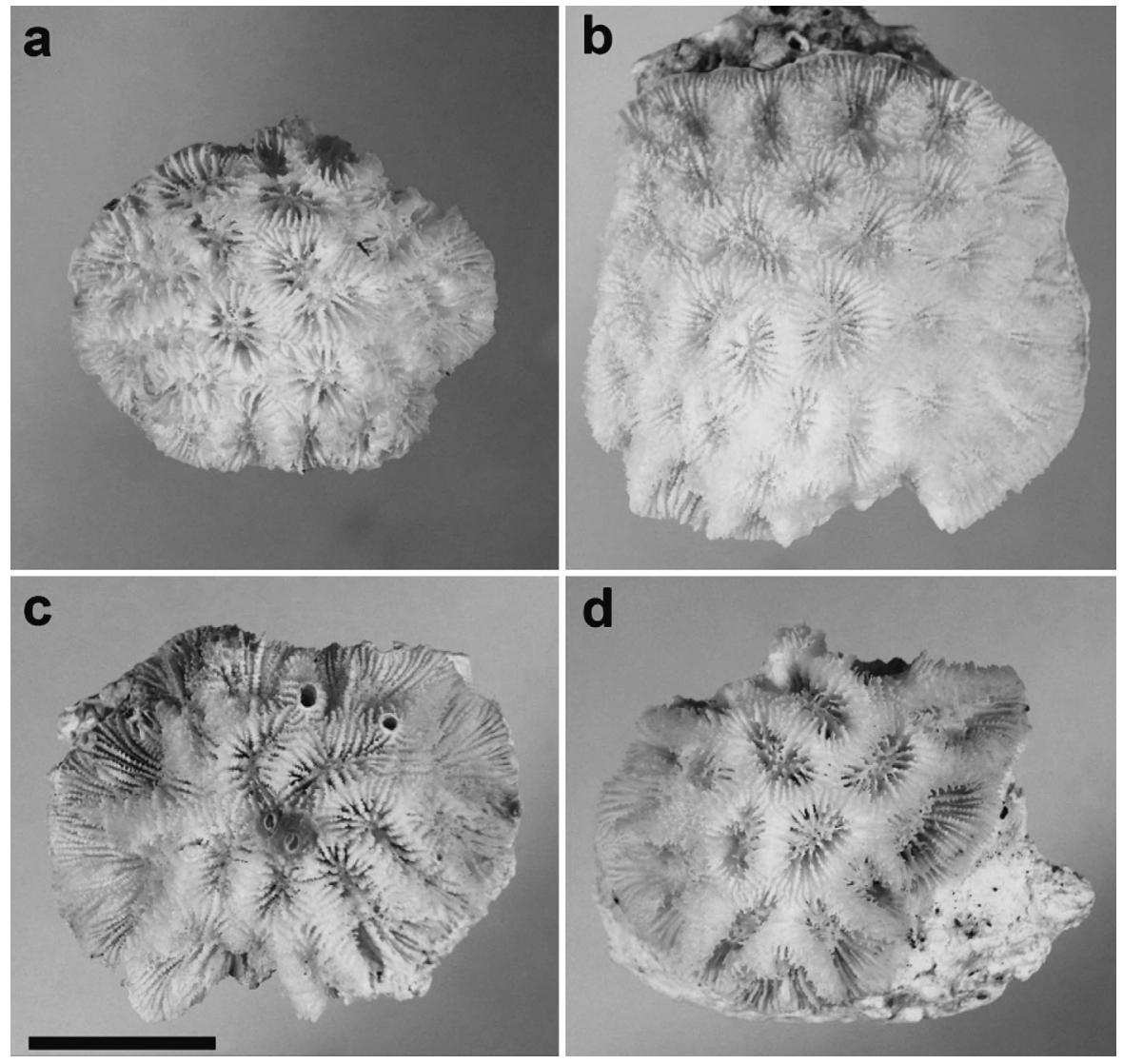

Fig. 2. Favia fragum. Morphological similarity of encrusting coral from the West and East Atlantic. Specimens from (a,b) Curaçao, formerly part of the Netherlands Antilles (Piscadera Bay, collected on 18 March 1974; ZMA Coel. 7568) and (c,d) the Cape Verde islands (SW coast of Sao Vicente, San Pedro Bay, collected on 21 June 1982; RMNH Coel. 16978). Scale bar: $1 \mathrm{~cm}$ (applies to all panels) 

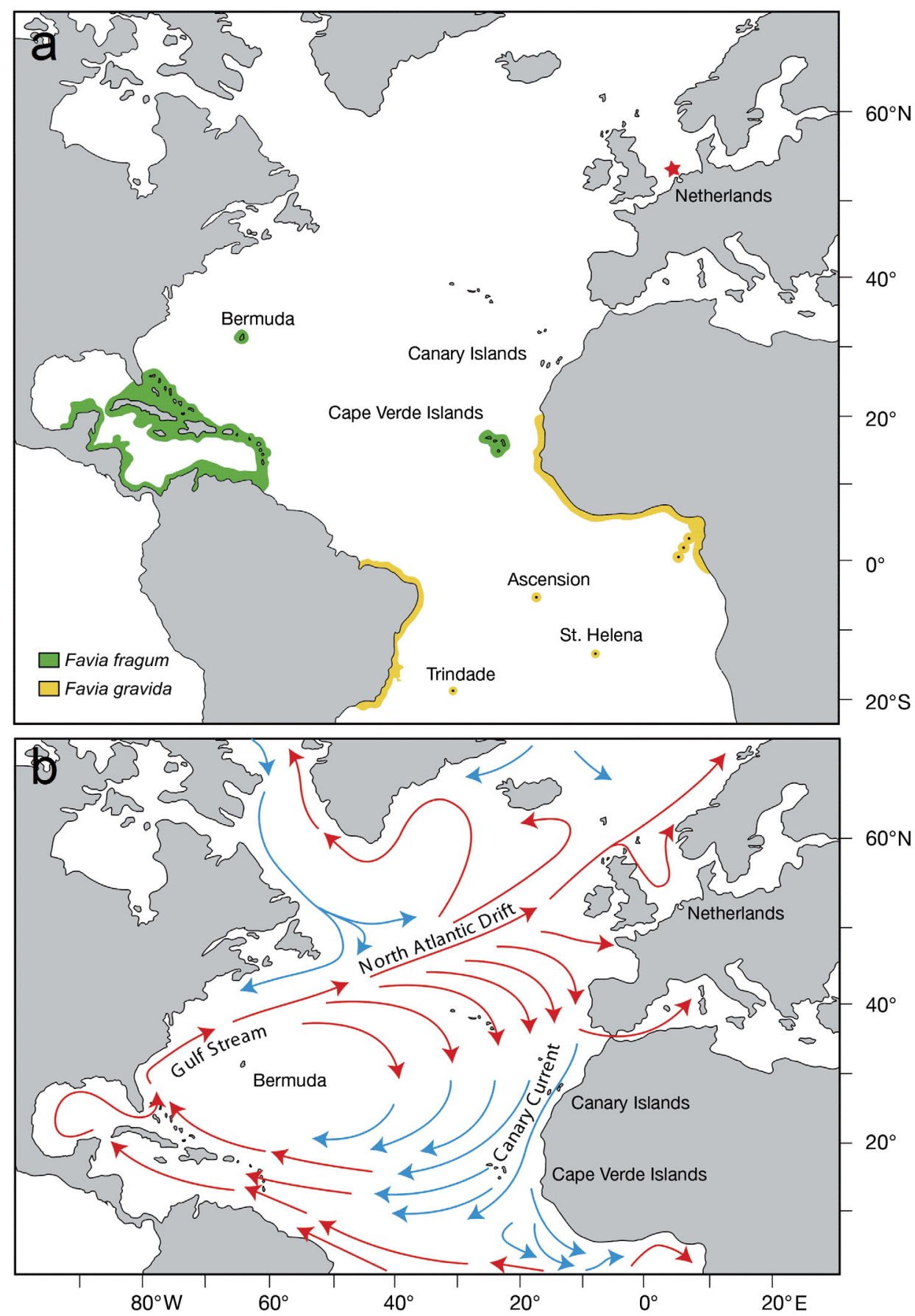

Fig. 3. Favia fragum and F. gravid. (a) Distribution ranges (after Laborel 1974, Aronson et al. 2008). The location of the dead beached specimens is indicated by a red star. (b) Course of the Gulf Stream and North Atlantic Drift from the Caribbean to western Europe (red = warm water current, blue = cool water current; http://www.noc.soton.ac.uk/rapid/sis/popups/ gulf_stream.php; used with permission from National Oceanography Centre, Southampton; see also USASF 1943)

spherical, with small corallites $(\varnothing<0.5 \mathrm{~cm})$, and an irregular septal ornamentation (Roos 1971, Fig. 2). The type of F. fragum from 'the southern American seas' (translated from Esper 1795) is missing (Scheer 1990), but Esper's (1793) illustrations are clear enough to confirm the identity of our specimens.
The distribution of Favia fragum ranges from the Caribbean and Bermuda (northernmost locality) to the Cape Verde Islands (Laborel 1974, Boekschoten \& Borel Best 1988, Fig. 3a). The skeleton morphology does not show clear intraspecific variation between the west and east Atlantic (Fig. 2) and can therefore 
not help to indicate the origin of the beached specimens.

The species resembles its congener Favia gravida, a predominantly littoral species with longer calices. Both species have amphi-Atlantic distributions but they are genetically distant species (Nunes et al. 2008, 2011) and show no range overlap (Laborel 1974, Hoeksema in press, Fig. 3a).

\section{Origin of the marine fauna on the stranded gas cylinder}

The remains of the other epifauna helped to reconstruct its west Atlantic origin (Cadée \& CadéeCoenen 2010). A small bivalve hidden in one of the barnacles belongs to the gray pygmy venus shell Timoclea grus (Holmes, 1858), which has a distribution range from Louisiana and the west coast of Florida to the Atlantic coast of Florida and North Carolina, southeast USA (Tucker Abott 1954, Warmke \& Tucker Abott 1961, Turgeon et al. 2009). Representatives of 2 other bivalves belong to species with a subtropical amphi-Atlantic distribution: the crested oyster Ostrea equestris (Say, 1834) and the corrugate jewelbox Chama congregata (Conrad, 1833). Shells of bivalves with an even wider, more northward Atlantic distribution range were also present, i.e. Hiatella arctica (Linnaeus, 1767) and Gastrochaena dubia (Pennant, 1777). The barnacles covering large parts of the cylinder belong to Balanus trigonus Darwin, 1854, originally a Pacific species but now dispersed worldwide in the subtropical seas as fouling on ships (Cadée 2011). The subtropical species represented on the gas cylinder, in particular Favia fragum and $T$. grus, have overlapping distribution ranges in southern Florida.

\section{DISCUSSION}

\section{The Gulfstream track}

Within the geographical range of Favia fragum, the Cape Verde Islands are the closest locality to the Netherlands (Fig. 3a). However, it is doubtful that the Texel specimens came from there because there are no oceanic currents that confirm such a track (Fig. 3b). Based on the course of the Gulf Stream and the North Atlantic Drift and the range overlap of the associated fauna on the cylinder, the most likely origin would be southern Florida. The corals could also have settled in the Caribbean, after which the cylinder became inhabited by the bivalve Timoclea grus at the southeastern coastline of the USA along the Gulf Stream track (Fig. 3b). Various estimates have been made regarding the expected time interval for passive eastward longrange dispersal from the southeastern USA to western Europe, ranging at least 14 to 18 mo (Guppy 1917, Cadée 2008, Bonhommeau et al. 2009), but if the cylinder would have entered the Columbus gyre, the expected travel time could have lasted $3 \mathrm{yr}$ extra or more (Ebbesmeyer \& Scigliano 2009). The corals themselves were not overgrown by other organisms (like barnacles), which indicates that they may have been dead for a short time when the cylinder washed ashore.

\section{Settlement and age of rafting corals: a life history}

In order to be a successful rafter a species needs a life-history strategy that facilitates settlement on floating substrates, and it has to live long enough to reach a suitable destination. The brooding coral Favia fragum is a simultaneous hermaphrodite with high rates of self-fertilization during lunar cycles of gametogenesis and planulation (Szmant-Froelich et al. 1985, Brazeau et al. 1998, Gleason et al. 2001, Carlon 2002, Goodbody-Gringley 2010). Planulation is monthly throughout the year in the Caribbean (Szmant 1986, Soong 1991) or seasonal at higher latitude (Bermuda), usually taking place before the water temperature reaches its maximum (GoodbodyGringley \& de Putron 2009). Therefore the corals on the cylinder must have settled when the cylinder was in close proximity to a reef where planulation took place, most likely year-round.

Favia fragum larvae survive only a few days after release. They are initially phototaxic but become rapidly negatively buoyant and settle on dark surfaces in clusters close to their parents (Lewis 1974a,b, Carlon \& Olson 1993, Carlon 2002, Petersen et al. 2007, Norström \& Sandström 2010). They prefer horizontal, flat, uneven surfaces for settlement (Petersen et al. 2005a,b, 2007). Because the cylinder was floating (reaching not deeper than $1.5 \mathrm{~m}$ ), the larvae probably settled on it when they were still phototaxic. The cylinder may already have been rusty at that time (Fig. 1), providing the larvae with a rough surface for attachment. In shallow water, the cylinder may have been touching the reef bottom but during its journey in open water, it could have been deeply submerged and perhaps in vertical position considering its heavy weight. 
The corals on the cylinder were relatively large $(5.5 \mathrm{~cm})$. In their first 2 to 4 yr Favia fragum corals grow rapidly, after which they grow more slowly (Vaughan 1916). They have been estimated to grow $16 \mathrm{~mm}$ in diameter per year in a growth range from 11 to $27 \mathrm{~mm}$ (Van Moorsel 1988). They have a fast generation turnover and can become fertile within $1 \mathrm{yr}$, implying that they reach maturity when they are still very small with even marginal polyps able to produce gonads (Soong \& Lang 1992, Petersen et al. 2007). The maximum corallum size in F. fragum is smaller $(<10 \mathrm{~cm})$ in comparison with many other Atlantic coral species and appears to be related to its reproductive strategy as a brooder (Vaughan 1916, Soong 1993). They start to die when they reach a size at which other species are considered juveniles (Edmunds 2000). The corals on the cylinder may have been about $3 \mathrm{yr}$ old when they died, which would have given them more than enough time to survive up to 14 to 18 mo and cross over the Atlantic. If they had reached a suitable habitat, they may also have been able to reproduce soon after due to early maturity and self-fertilization.

\section{Rafting opportunities: substratum and depth preferences}

In order to use rafting as a means for long-range dispersal, Favia fragum must be able to live on floating substrates. Favia fragum is able to grow on many kinds of shallow water substrates $(<15 \mathrm{~m}$, predominantly $<3 \mathrm{~m}$ depth), including inland waters (Roos 1971, Bak 1975, Carlon 2002). They generally grow on solid substrate remote from sand, which may even consist of erect branches of alcyonarians (Kissling 1965). F. fragum has been found growing on mangrove prop roots but with no mention of potential buoyancy and dispersal (Roos 1964, 1971, Rogers 2009). Their larvae can settle on thalli of the calcareous green alga Halimeda opuntia, although it is not expected that recruits will reach adult size due to the short life span of the thallus segments (Nugues \& Szmant 2006). Because the species occurs at both sides of the Atlantic, it may use firm floating substrates for long-distance dispersal, which is supported by the present observation.

Adult Favia fragum corals may resist exposure to air and high temperatures, enabling them to survive in shallow water heated by the sun (Vaughan 1916, Mayer 1917). On the other hand, their larvae cannot endure long exposure to elevated seawater temperature $\left(31^{\circ} \mathrm{C}\right)$ (Randall \& Szmant 2009). If they settle on the shaded side of a floating substrate, recruits risk exposure to air and sunlight if the drifting substrate rolls over. Nevertheless, corals of this shallow-water species are well able to resist heat exposure and show much intraspecific morphological variation, which enables them to survive in various environments (Roos 1971, Carlon \& Budd 2002).

Eventually, rafting corals die when they reach cold water and they are not successful colonizers unless their offspring reach a suitable substrate first. Edinger \& Risk (1994) considered Favia fragum coldtolerant compared to other Caribbean corals. Adult F. fragum are also able to endure cold water $\left(14^{\circ} \mathrm{C}\right)$ for short periods but not without damage (Mayer 1914), which agrees with the general pattern that Atlantic reef corals are sensitive to temperatures below $16^{\circ} \mathrm{C}$ (Burns 1985). This implies that the range limits for $F$. fragum depend on seasonal temperature fluctuations (Fig. 4). They may survive travel longer in the summer than in winter, but eventually they are limited by minimum winter temperatures. In their present range, Bermuda in the West Atlantic appears to be the coldest area where they persevere, with a minimum temperature of $20^{\circ} \mathrm{C}$ (Figs. $3 \& 4$ ), whereas surface water in the more southward Cape Verde Islands in the East Atlantic is about $22^{\circ} \mathrm{C}$.

\section{Natural substrates of rafting corals}

Jackson (1986) argued that the wide distribution ranges of brooding Atlantic reef corals (including Favia fragum) can only be explained by rafting. Some reef corals are known to become floatable after exposure to air without a floating substrate (Kornicker \& Squires 1962). Although, driftwood in the form of trees is used by many rafting organisms (Thiel \& Haye 2006), this has not yet been observed for corals. A likely natural substrate for rafting reef corals is volcanic drift pumice (Jokiel 1984, 1989, 1990a,b, Jokiel \& Cox 2003), which has indeed been reported from the North Atlantic (Binns 1972) and may stay afloat long enough to enable dispersal by rafting (Whitham \& Sparks 1986, Bravo et al. 2011). Dead unattached corals may become buoyant due to gas production and become rafting substrates themselves (DeVantier 1992).

\section{Rafting corals on man-made substrates}

There is little information on rafting by corals on anthropogenic substrates. All available records concern dead specimens. Boekschoten \& Borel Best 

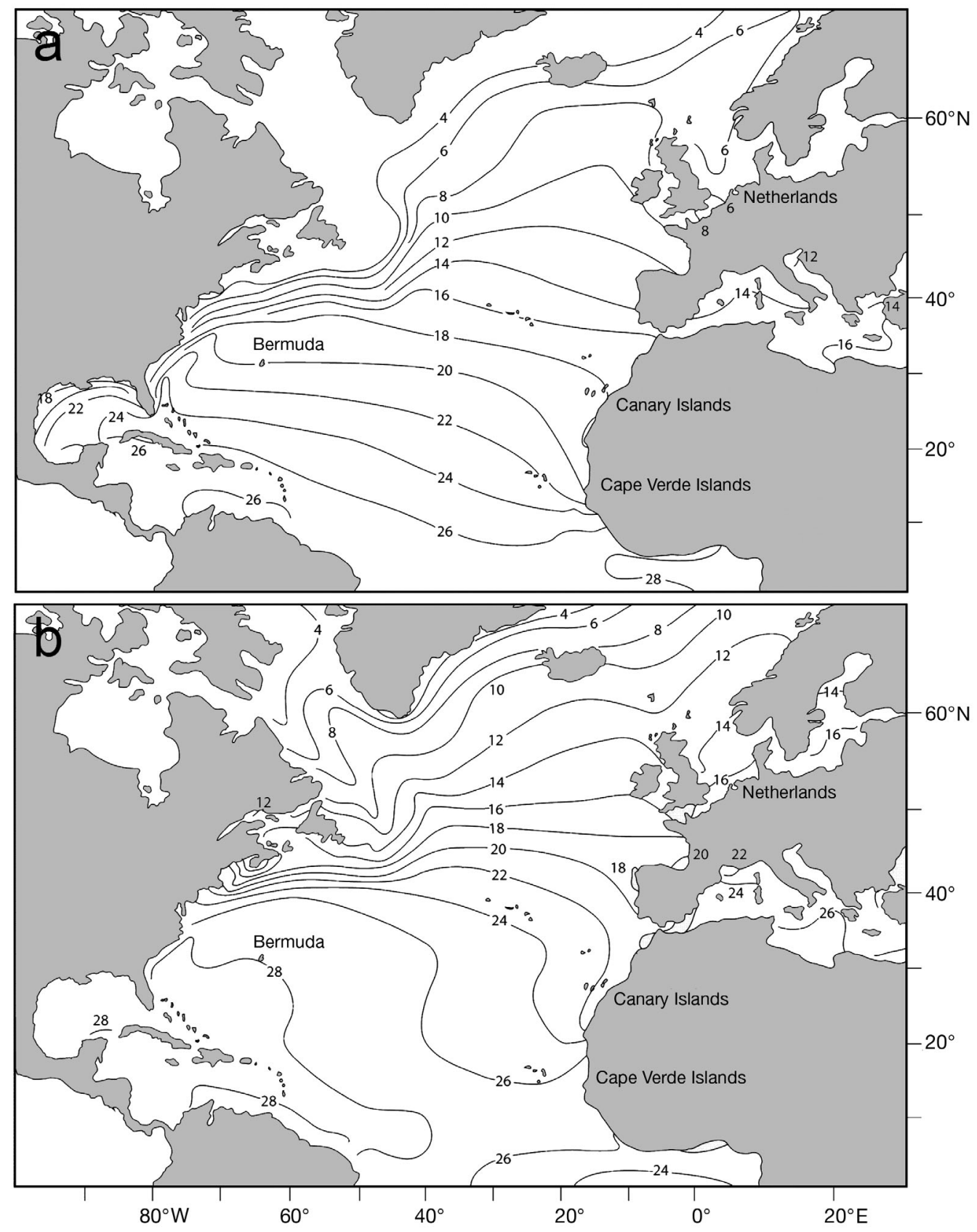

Fig. 4. (a) Winter (February) and (b) summer (August) isotherms of surface water in the northern Atlantic (source Cambridge et al. 1987)

(1988) argue that the presence of dead Favia corals on Brazilian cobbles along Cape Verdian coastlines can be explained by their use as ballast in salt vessels from Brazil. They resemble F. gravida corals from the coast of West Africa and Brazilian waters (Laborel 1974, Amaral \& Ramos 2007).

The present case of Favia fragum corals reaching the Netherlands is the first record of a tropical zooxanthellate coral species for the North Sea. Previous records of scleractinians in the Netherlands (e.g.
Adema 1987, 1995) concern dead specimens of Northeast Atlantic species (Zibrowius 1980), like azooxanthellate Devonshire cup corals, Caryophyllia smithii Stokes \& Broderip, 1828, on various plastic objects and a piece of bitumen, and specimens of Thalamophyllia gasti (Döderlein, 1913) on a glass fish net buoy. These records suggest that man-made objects may serve well as substrates for corals, which may enlarge their chances for long-distance dispersal. 


\section{Rafting corals and sea water warming}

Rising seawater temperatures will cause summer and winter sea water surface isotherms to shift towards higher latitudes, which may facilitate the settlement of zooxanthellate corals in areas where they previously did not occur. Recent examples of range shifts among reef corals concern species occurring along continuous coastlines (Florida, West Australia, Japan), possibly through larval dispersal (Precht \& Aronson 2004, Greenstein \& Pandolfi 2008, Yamano et al. 2011). Examples of non-indigenous corals that showed range expansion after settlement are Indo-Pacific azooxanthellate Tubastraea species entering the West Atlantic, most likely as fouling on ships or oil rigs (Fenner \& Banks 2004, Hoeksema et al. 2011, Mantelatto et al. 2011). An example of a zooxanthellate coral invading European waters is Oculina patagonica De Angelis, 1908, which is presumed to be of temperate AtlanticSouth American origin. It has been recorded in the Mediterranean since 1966, where it probably arrived by a ship because it was first found in and around harbours (Fine et al. 2001, Sartoretto et al. 2008). An example of a tropical zooxanthellate coral settling in subtropical water is the hydrocoral Millepora in the Canary Islands, where the seawater is reported to range between 18 and $25^{\circ} \mathrm{C}$ (Clemente et al. 2010), whereas earlier sources mention 18 to $22^{\circ} \mathrm{C}$ (Cambridge et al. 1987, Earle, 2000). Millepora corals are known to use pumice as rafting substrate (Jokiel 1989), which may also have been the case in the Canary Islands. A winter temperature of $18^{\circ} \mathrm{C}$ is warmer than the tolerance limit of $16^{\circ} \mathrm{C}$ for Caribbean corals (Burns 1985) and certainly for Favia fragum, which is considered more cold-tolerant than many other reef coral species (Edinger \& Risk 1994). With rising seawater temperatures the Canary Islands would indeed be a likely candidate for the settlement of reef corals drifting across the Atlantic (Fig. 4).

\section{CONCLUSIONS}

The present case indicates (1) that brooding reef corals can survive for periods that are long enough to enable long-distance dispersal through rafting, (2) that the availability of man-made flotsam may contribute to this, and (3) that seawater warming may help brooding reef corals to expand their ranges towards regions that at present are still considered subtropical.
Acknowledgements. V. Byfield (National Oceanography Centre, Southampton) gave permission for use of Fig. 3b. The type specimens of Favia gravida were sent on loan by E. Lazo Wasem (Yale Peabody Museum, New Haven, CT) and the specimens of $F$. fragum from Curaçao by E. Beglinger (Zoological Museum Amsterdam, ZMA). R.G. Moolenbeek (ZMA) and J. Goud (Netherlands Centre for Biodiversity Naturalis, Leiden Naturalis) checked the identity of the mollusks. G.C.C. thanks the directors of the Royal NIOZ for room and facilities they provide for him after his retirement.

\section{LITERATURE CITED}

Adema JPHM (1987) Een glazen drijver van een visnet aangespoeld op het strand tussen Katwijk en Noordwijk. Het Zeepaard 47:146-152

Adema JPHM (1995) De Nederlandse steenkoralen (Coelenterata, Anthozoa, Scleractinia): een monografie. Het Zeepaard 55:96-100

Aliani S, Molcard A (2003) Hitch-hiking on floating marine debris: macrobenthic species in the Western Mediterranean Sea. Hydrobiologia 503:59-67

Amaral FD, Ramos CAC (2007) Skeletal variability of the coral Favia gravida (Verrill, 1868) from Brazil. Biota Neotrop 7:245-251

Aronson R, Bruckner A, Moore J, Precht B, Weil E (2008) Favia fragum. In: IUCN 2010. IUCN Red List of Threatened Species. Version 2010.4. www.iucnredlist.org

Bak RPM (1975) Ecological aspects of the distribution of reef corals in the Netherlands Antilles. Bijdr Dierk 45: 181-190

Barnes DKA (2002) Invasions by marine life on plastic debris. Nature 416:808-809

> Barnes DKA, Fraser KPP (2003) Rafting by five phyla on man-made flotsam in the Southern Ocean. Mar Ecol Prog Ser 262:289-291

Barnes DKA, Milner P (2005) Drifting plastic and its consequences for sessile organism dispersal in the Atlantic Ocean. Mar Biol 146:815-825

Binns RE (1972) Composition and derivation of pumice on postglacial strandlines in northern Europe and the Western Arctic. Geol Soc Am Bull 83:2303-2324

Boekschoten GJ, Borel Best M (1988) Fossil and recent shallow water corals from the Atlantic islands off Western Africa. Zool Meded 62:99-112

Bonhommeau S, Blanke B, Tréguier AM, Grima N and others (2009) How fast can the European eel (Anguilla anguilla) larvae cross the Atlantic Ocean? Fish Oceanogr 18:371-385

- Bravo M, Astudillo JC, Lancellotti D, Luna-Jorquera G, Valdivia N, Thiel M (2011) Rafting on abiotic substrata: properties of floating items and their influence on community succession. Mar Ecol Prog Ser 439:1-17

- Brazeau DA, Gleason DF, Morgan ME (1998) Self-fertilization in brooding hermaphroditic Caribbean corals: evidence from molecular markers. J Exp Mar Biol Ecol 231: 225-238

Burns TP (1985) Hard-coral distribution and cold-water disturbances in South Florida. Coral Reefs 4:117-124

Cadée GC (2008) Gulf stream coconuts. The Harries-Baker test for discrimination between flotsam/jetsam and natural dissemination. Palms 52:19-21

Cadée GC (2011) Balanus trigonus Darwin, 1854 op de op Texel aangespoelde gascilinder. Het Zeepaard 71:69-70 
Cadée GC, Cadée-Coenen J (2010) Timoclea grus (Holmes, 1858) en andere tropische tweekleppigen van een op Texel aangespoelde gascilinder. Spirula 373:49-52

Cambridge ML, Breeman AM, Kraak S, van den Hoek C (1987) Temperature responses of tropical to warm temperate Cladophora species in relation to their distribution in the North Atlantic Ocean. Helgol Meersunters 41: 329-354

> Carlon DB (2002) Production and supply of larvae as determinants of zonation in a brooding tropical coral. J Exp Mar Biol Ecol 268:33-46

> Carlon DB, Budd AF (2002) Incipient speciation across a depth gradient in a scleractinian coral? Evolution 56: 2227-2242

> Carlon DB, Olson RR (1993) Larval dispersal distance as an explanation for adult spatial pattern in two Caribbean reef corals. J Exp Mar Biol Ecol 173:247-263

Cheng L (1975) Marine pleuston-animals at the sea-air interface. Oceanogr Mar Biol Annu Rev 13:181-212

> Clemente S, Rodríguez A, Brito A, Ramos A, Monterroso Ó, Hernández JC (2010) On the occurrence of the hydrocoral Millepora (Hydrozoa: Milleporidae) in the subtropical eastern Atlantic (Canary Islands): Is the colonization related to climatic events? Coral Reefs 30:237-240

> Derraik JGB (2002) The pollution of the marine environment by plastic debris: a review. Mar Pollut Bull 44:842-852

$>$ DeVantier LM (1992) Rafting of tropical marine organisms on buoyant corolla. Mar Ecol Prog Ser 86:301-302

> Donohue MJ, Boland RC, Sramek CM, Antonelis GA (2001) Derelict fishing gear in the Northwestern Hawaiian Islands: diving surveys and debris removal in 1999 confirm threat to coral reef ecosystems. Mar Pollut Bull 42: 1301-1312

Earle SA (2000) Atlas of the ocean: the deep frontier. National Geographic, Washington DC

Ebbesmeyer C, Scigliano E (2009) Flotsametrics and the floating world. Collins, New York, NY

> Edinger EN, Risk MJ (1994) Oligocene-Miocene extinction and geographic restriction of Caribbean corals; roles of turbidity, temperature, and nutrients. Palaios 9:576-598

Edmunds PJ (2000) Patterns in the distribution of juvenile corals and coral reef community structure in St. John, US Virgin Islands. Mar Ecol Prog Ser 202:113-124

Esper EJC (1793-1795) Die Planzenthiere: Fortsetzungen 1: 1-230. Abbildungen I: Madrepora pls. 1-87. Raspischen Buchhandlung, Nurnberg

Fenner D, Banks K (2004) Orange Cup Coral Tubastraea coccinea invades Florida and the Flower Garden Banks, Northwestern Gulf of Mexico. Coral Reefs 23:505-507

> Fine M, Zibowius H, Loya Y (2001) Oculina patagonica: a non-lessepsian scleractinian coral invading the Mediterranean Sea. Mar Biol 138:1195-1203

Fraser CI, Nikula R, Waters JM (2011) Oceanic rafting by a coastal community. Proc Biol Sci 278:649-655

Gleason DF, Brazeau DA, Munfus D (2001) Can self-fertilizing coral species be used to enhance restoration of Caribbean reefs? Bull Mar Sci 69:933-943

> Goodbody-Gringley G (2010) Diel planulation by the brooding coral Favia fragum (Esper, 1797). J Exp Mar Biol Ecol 389:70-74

> Goodbody-Gringley G, de Putron SJ (2009) Planulation patterns of the brooding coral Favia fragum (Esper) in Bermuda. Coral Reefs 28:959-963

Goodbody-Gringley G, Vollmer SV, Woollacott RM, Giribet G (2010) Limited gene flow in the brooding coral Favia fragum (Esper, 1797). Mar Biol 157:2591-2602

Greenstein BJ, Pandolfi JM (2008) Escaping the heat: range shifts of reef coral taxa in coastal Western Australia. Glob Change Biol 14:513-528

> Gregory MR (2009) Environmental implications of plastic debris in marine settings-entanglement, ingestions, smothering, hangers-on, hitch-hiking and alien invasions. Philos Trans R Soc Lond B 364:2013-2025

Guppy HB (1917) Plants, seeds, and currents in the West Indies and Azores: the results of investigations carried out in those regions between 1906 and 1914. Williams and Norgate, London

Harrold C, Lisin S (1989) Radio-tracking rafts of giant kelp: local production and regional transport. J Exp Mar Biol Ecol 130:237-251

Hess NA, Ribic CA, Vining I (1999) Benthic marine debris, with an emphasis on fishery-related items, surrounding Kodiak Island, Alaska, 1994-1996. Mar Pollut Bull 38: 885-890

Highsmith RC (1985) Floating and algal rafting as potential dispersal mechanisms in brooding invertebrates. Mar Ecol Prog Ser 25:169-179

Hoeksema BW (2012) Extreme morphological plasticity enables a free mode of life in Favia gravida at Ascension Island (South Atlantic). Mar Biodiv dio:10.1007/s12526011-0106-z

Hoeksema BW, Van der Land J, Van der Meij SET, Van Ofwegen LP, Reijnen BT, Van Soest RWM, De Voogd NJ (2011) Unforeseen importance of historical collections as baselines to determine biotic change of coral reefs: the Saba Bank case. Mar Ecol 32:135-141

Jackson JBC (1986) Modes of dispersal of clonal benthic invertebrates: consequences for species' distributions and genetic structure of local populations. Bull Mar Sci 39:588-606

Jokiel PL (1984) Long distance dispersal of reef corals by rafting. Coral Reefs 3:113-116

Jokiel PL (1989) Rafting of reef corals and other organisms at Kwajalein Atoll. Mar Biol 101:483-493

> Jokiel PL (1990a) Transport of reef corals into the Great Barrier Reef. Nature 347:665-667

> Jokiel PL (1990b) Long-distance dispersal by rafting: reemergence of an old hypothesis. Endeavour 14:66-73

Jokiel PL, Cox EF (2003) Drift pumice at Christmas Island and Hawaii: evidence of oceanic dispersal patterns. Mar Geol 202:121-133

Jones MM (1995) Fishing debris in the Australian marine environment. Mar Pollut Bull 30:25-33

Kissling DL (1965) Coral distribution on a shoal in Spanish Harbor, Florida Keys. Bull Mar Sci 15:599-611

> Kornicker LS, Squires DF (1962) Floating corals: a possible source of erroneous distribution data. Limnol Oceanogr $7: 447-452$

Laborel J (1974) West African reef corals: a hypothesis on their origin. Proc 2nd Int Coral Reef Symp 1:425-442

> Lewis JB (1974a) The settlement behavior of planulae larvae of the hermatypic coral Favia fragum (Esper). J Exp Mar Biol Ecol 15:165-172

Lewis JB (1974b) The importance of light and food upon the early growth of the reef coral Favia fragum (Esper). J Exp Mar Biol Ecol 15:299-304

Mantelatto MC, Creed JC, Mourão GG, Migotto AE, Lindner A (2011) Range expansion of the invasive corals Tubastraea coccinea and Tubastraea tagusensis in the Southwest Atlantic. Coral Reefs 30:397 
Mayer AG (1914) The effects of temperature upon tropical marine animals. Pap Tortugas Lab Carnegie Inst Wash 6: $1-24$

Mayer AG (1917) Is death from high temperature due to the accumulation of acid in the tissues? Am J Physiol 44: 581-585

Norström AV, Sandström M (2010) Lipid content of Favia fragum larvae: changes during planulation. Coral Reefs 29:793-795

> Nugues MM, Szmant AM (2006) Coral settlement onto Halimeda opuntia: A fatal attraction to an ephemeral substrate? Coral Reefs 25:585-591

> Nunes F, Fukami H, Vollmer SV, Norris RD, Knowlton N (2008) Re-evaluation of the systematics of the endemic corals of Brazil by molecular data. Coral Reefs 27: 423-432

> Nunes FLD, Norris RD, Knowlton N (2011) Long distance dispersal and connectivity in amphi-Atlantic corals at regional and basin scales. PLoS ONE 6:e22298 doi: 10.1371/journal.pone.0022298

Petersen D, Laterveer M, Schuhmacher H (2005a) Innovative substrate tiles to spatially control larval settlement in coral culture. Mar Biol 146:937-942

Petersen D, Laterveer M, Schuhmacher H (2005b) Spatial and temporal variation in larval settlement of reefbuilding corals in mariculture. Aquaculture 249:317-327

> Petersen D, Laterveer M, Visser G (2007) Sexual recruitment of the corals Favia fragum and Agaricia humilis in a 30$\mathrm{m}^{3}$ exhibit aquarium: species-specific limitations and implications on reproductive ecology. Zoo Biol 26:75-91

Precht WF, Aronson RB (2004) Climate flickers and range shifts of reef corals. Front Ecol Environ 2:307-314

> Randall CJ, Szmant AM (2009) Elevated temperature reduces survivorship and settlement of the larvae of the Caribbean scleractinian coral, Favia fragum (Esper). Coral Reefs 28:537-545

Richards ZT, Beger M (2011) A quantification of the standing stock of macro-debris in Majuro lagoon and its effect on hard coral communities. Mar Pollut Bull 62:1693-1701

Rogers CS (2009) High diversity and abundance of scleractinian corals growing on and near mangrove prop roots, St. John, US Virgin Islands. Coral Reefs 28:909

Roos PJ (1964) The distribution of reef corals in Curaçao. Stud Fauna Curaçao Caribb Isls 20:1-51

Roos PJ (1971) The shallow-water corals of the Netherlands Antilles. Stud Fauna Curaçao Caribb Isls 130:1-50

Ryan PG, Moore CJ, van Franeker JA, Moloney CL (2009) Monitoring the abundance of plastic debris in the marine environment. Philos Trans R Soc Lond B 364:1999-2012

Sartoretto S, Harmelin JG, Bachet F, Bejaoui N, Lebrun O, Zibrowius H (2008) The alien coral Oculina patagonica De Angelis, 1908 (Cnidaria, Scleractinia) in Algeria and Tunisia. Aquat Invasions 3:173-180

Scheer G (1990) Die von E.J.C. Esper 1788-1809 beschriebenen Anthozoa (Cnidaria). IV. Scleractinia. V. Espers Leben und Werk. Senckenb Biol 71:369-429

Soong K (1991) Sexual reproductive patterns of shallowwater reef corals in Panama. Bull Mar Sci 49:832-846

Soong K (1993) Colony size as a species character in massive reef corals. Coral Reefs 12:77-83

Soong K, Lang JC (1992) Reproductive integration in reef corals. Biol Bull 183:418-431

Szmant AM (1986) Reproductive ecology of Caribbean reef

Editorial responsibility: Charles Birkeland,

Honolulu, Hawaii, USA corals. Coral Reefs 5:43-54

Szmant-Froelich A, Reutter M, Riggs L (1985) Sexual reproduction of Favia fragum (Esper): lunar patterns of gametogenesis, embryogenesis and planulation in Puerto Rico. Bull Mar Sci 37:880-892

Taffs KH, Cullen MC (2005) The distribution and abundance of marine debris on isolated beaches of northern New South Wales, Australia. Australas J Environ Manage 12: 244-250

Thiel M, Gutow L (2005a) The ecology of rafting in the marine environment. I. The floating substrata. Oceanogr Mar Biol Annu Rev 42:181-264

Thiel M, Gutow L (2005b) The ecology of rafting in the marine environment. II. The rafting organisms and community. Oceanogr Mar Biol Annu Rev 43:279-418

Thiel M, Haye PA (2006) The ecology of rafting in the marine environment. III. Biogeographical and evolutionary consequences. Oceanogr Mar Biol Annu Rev 44: 323-429

> Thiel M, Hinojosa I, Vasquez N, Macaya E (2003) Floating marine debris in coastal waters of the SE-Pacific (Chile). Mar Pollut Bull 46:224-231

Tucker Abbott R (1954) American seashells. Nostrand, Princeton

Turgeon DD, Lyons WG, Mikkelsen P, Rosenberg G, Moretzsohn F (2009) Bivalvia (Mollusca) of the Gulf of Mexico. In: Felder DL, Camp DK (eds) Gulf of Mexico origin, waters, and biota: biodiversity. Texas A\&M Press, College Station, p 711-744

- Uneputty PA, Evans SM (1997) Accumulation of beach litter on islands of the Pulau Seribu Archipelago, Indonesia. Mar Pollut Bull 34:652-655

USASF (1943) Ocean currents and sea ice. Atlas of World Maps. United States Army Service Forces Manual M-101 Department of State, Washington DC

Van Moorsel GWNM (1988) Early maximum growth of stony corals (Scleractinia) after settlement on artificial substrata on a Caribbean reef. Mar Ecol Prog Ser 50:127-135

Vaughan TW (1916) The results of investigations of the ecology of the Floridian and Bahaman shoal-water corals. Proc Natl Acad Sci USA 2:95-100

Warmke GL, Tucker Abbott R (1961) Caribbean Seashells. Livingston Publishing, Narberth, Pennsylvania

Whitham AG, Sparks RSJ (1986) Pumice. Bull Volcanol 48: 209-223

Willoughby NG, Sangkoyo H, Lakaseru BO (1997) Beach litter: an increasing and changing problem for Indonesia. Mar Pollut Bull 34:469-478

Winston JE (1982) Drift plastic-an expanding niche for a marine invertebrate? Mar Pollut Bull 13:348-351

Winston JE, Gregory MR, Stevens LM (1997) Encrusters, epibionts, and other biota associated with pelagic plastics: a review of biogeographical, environmental, and conservation issues. In: Coe JM, Rogers DB (eds) Marine debris: sources, impacts, and solution. Springer, New York, NY, p 81-97

Yamano H, Sugihara K, Nomura K (2011) Rapid poleward range expansion of tropical reef corals in response to rising sea surface temperatures. Geophys Res Lett 38: L04601. doi:10.1029/2010GL046474

Zibrowius H (1980) Les scleractiniaires de la Mediterranée et de l'Atlantique nord-oriental. Mem Inst Oceanogr Monaco 11:1-284

Submitted: September 5, 2011; Accepted: October 22, 2011 Proofs received from author(s): January 3, 2012 